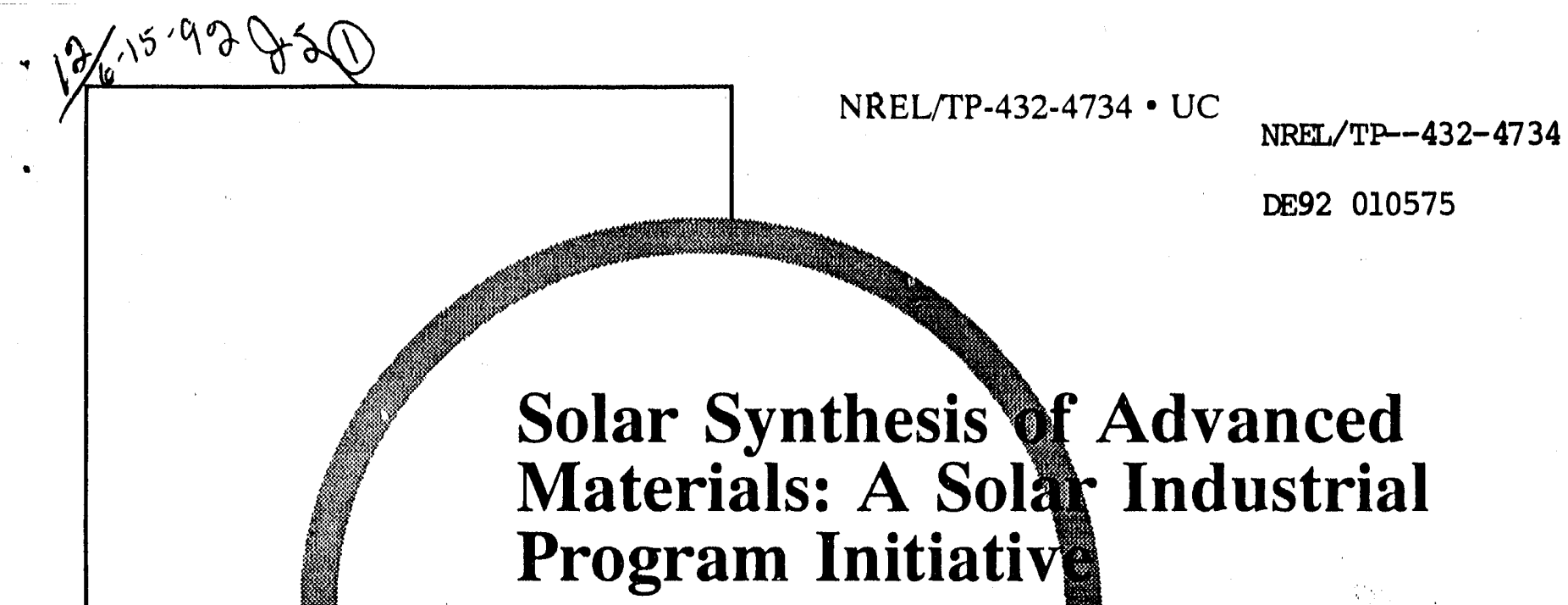

JUN 169992

Allan Lewandowski

National Renewable Energy Laboratory

(formerly the Solar Energy Research Institute)

1617 Cole Boulevard

Golden, Colorado 8()401-3393

A Division of Midwest Research Institute Operated for the U.S. Department of Energy under $\mathrm{Contract} \mathrm{N}($ ). DE-AC(02-83CH100)3

June 1992 


\section{On September 16, 1991 the Solar Energy Institute was designated a national laboratory, and its name was changed to the National Renewable Energy Laboratory.}

\section{NOTICE}

This report was prepared as an account of work sponsored by an agency of the United States government. Neither the United States government nor any agency thereot, nor any of their employees, makes any warranty, express or implied, or assumes any legal liability or responsibility for the accuracy. completeness, or usefulness of any information, apparatus, product, or process disclosed, or represents that its use would not infringe privately owned rights. Reference herein to any specific commercial product, process, or service by trade name, trademark, manufacturer, or otherwise does not necessarily constitute or imply its endorsement, recommendation, or favoring by the United States government or any agency thereof. The views and opinions of authors expressed herein do not necessarily state or reflect those of the United States government or any agency thereof

$$
\begin{gathered}
\text { Printed in the United States of America } \\
\text { Available from: } \\
\text { National Techrical Information Service } \\
\text { U.S. Department of Commerce } \\
5285 \text { Port Royal Road } \\
\text { Springtield, VA } 22161 \\
\text { Price: Microfiche A01 } \\
\text { Printed Copy A02 }
\end{gathered}
$$

Codes are used for pricing all publications. The code is determined by the number of pages in the publication. Intormation pertaining 10 the pricing codes can be found in the current issue of the following publications which are generally available in most libraries: Energy Research Abstracts (ERA); Government Reports Announcements and Index (GRA and I); Scientific and Technical Abstract Reports (STAR); and publication NTIS.PR-360 available from NTIS at the above address. 


\title{
Solar Synthesis of Advanced Materials: A Solar Industrial Program Initiative
}

\author{
Allan Lewandowski \\ National Renewable Energy Laboratory -1617 Cole Boulevard - Golden, Colorado USA 80401
}

\section{- INITIATIVE GOAL}

This is an initiative for accelerating the use of solar energy in the advanced materials manufacturing industry in the United States. The initiative will be based on government-industry collaborations that will develop the technology and help U.S. industry compete in the rapidly expanding global advanced materials marketplace.

\section{- BACKGROUND AND MARKETPIACE}

Advanced materials have an immense economic and strategic potential to strengthen the U.S. economy in the eoming decades. The estimated annual sales for advanced materials in the year 2()$(x)$ is more than $\$ 150$ billion in the United States and $\$ 40)$ billion worldwide. Figure 1 shows the predicted sales for advanced materials and other emerging technologies. To put these numbers in perspective, the National Energy Strategy estimates that consumers spent $\$ 160$ billion in 1989 on electricity.

The National Academy of Sciences recently concluded that "materials science and enginecring is crucial to the success of industries that are important (o) the strength of the U.S. economy and U.S. defense." However, the report went on to say that there is "...a serious weakness in the U.S. research effort in the synthesis and processing of materials." |11

\section{Annual Sales of $\$ 356$ Billion in U.S. by Year 2000}

EMERGING MATERIALS

- Advancerd Materials

- Superconducturs

EMERGING ELECTRONICS AND INFORMATION SYSTEMS

- Advanced Semiconductor Devices Digital Imaging Technology

- High-Density Data Storage High-Performance Computing

- Optoelectronics

EMERGING MANUFACTURING SYSTEMS

Artificial Intelligence

Flexible Computer-Integrated

Manufacturing

- Sensor Technology

EMERGING LIFE-SCIENCES APPLICATIONS

Biotechnology Medical Devices and Diagnostics

Emerging Technologies: A Survey of Technical \& Economic Opportunities" Department of Commerce Report, 9/90

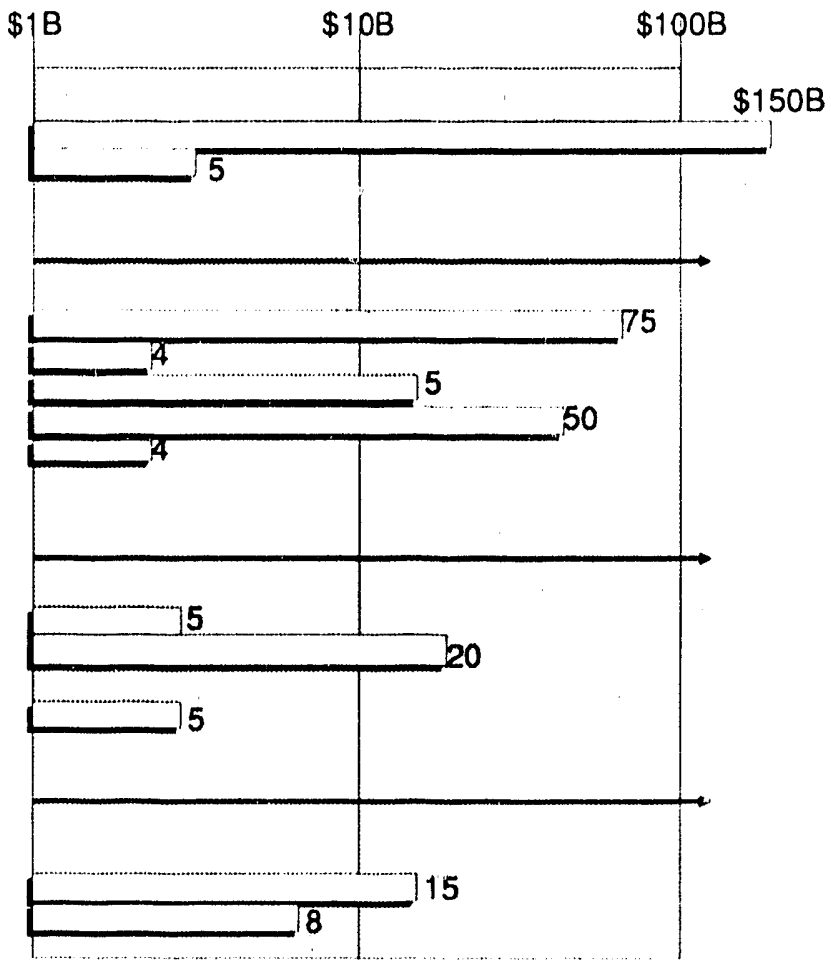

$9 \cdot 12 \cdot 28$

Figure 1. Emerging Technologies and Markets. [2]

Solar Synthesıs of Advanced Materıals: A Solar Industrial Program Initiatıve = Allan Lewandowskı 
International competitiveness is an important reason for the call for renewed U.S. focus on advanced materials. For the past 40) years, dominance in science and technology allowed the United States to maintain its position as the world's industrial leader. This dominance has rapidly eroded as Western Europe and Japan have taken an aggressive role in developing and commercializing many hightechnology products and processes. To remain competitive in this rapidly evolving international economic arena, U.S. industry must emphasize the research and development of new products and emerging technologies, and focus on product commercialization and enlarging its share of the global market. In collaboration with industry and universities, DOE and the National Renewable Energy Lahoratory (NREL) can contrihute expertise (1) this Urive for improving U.S. economic competitiveness in the growing advanced materials market.

Breakthroughs in soldar technology over the last 5 yours have crealed exceptional new foels for developing advanced materials. Concentralted sunlight from solar furnaces can produce intensities that approach these on the surlace of the sun and can generate temperatures well over $2,()(k){ }^{\circ} \mathrm{C}$. Very thin layers of illuminated surfaces can be driven $(0$ remarkably high temperatures in a fraction of a second. Concentrated solar energy can be delivered over large areas, allowing for rapid processing and high production rates. By using this technology, researchers are transforming low-cost raw materials into high-performance products. Soliur synthesis of advanced materials uses bulk materials and energy more efficiently, lowers processing costs, and reduces the need for strategic materials-all with a technology that does not harm the environment.

The Solar Industrial Program has huilt a unicye, world-class solar furnace at NREL to help meet the growing need for applied research in advanced malterials (see Figure 2). Many new advanced materials processes have heen successfully demonstrated in this facility, including the following:

- Metalorganic deposition is a rapidly growing alternative to electroplating and other techniques for forming certain types of thin films on solid substrates. This process, demonstrated on a numher of substrates with various metalorganic solutions, can he used for a wide variely of electricial and electronic applications (e.g., contacts, connectors, and high-performance electronic packages).
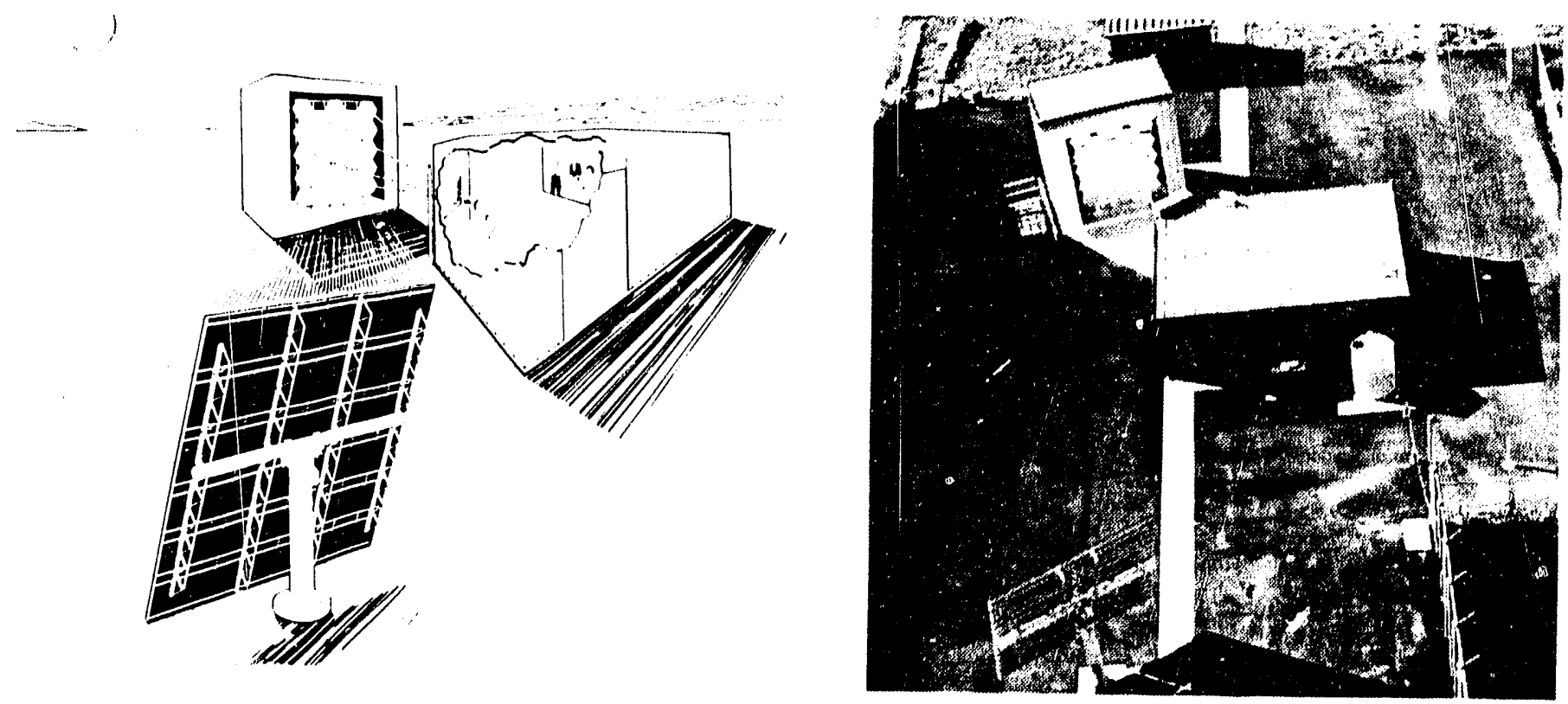

Figure 2. NREL's high-flux solar furnace. Left: Artist's conception of system operation. Right: The actual facility located on South Table Mountain in Golden, Colorado. 
- Ceramic powders have been produced in a solar reactor. These powders can be used for making low-wear and high-strength components, high-temperature and corrosion-resistant seals, bearings, cutting tools, linings, and other high-temperature products.

- Diamond-like carbon materials of high quality and uniform thickness have been formed in the solar furnace using chemical vapor deposition techniques. These materials have exceedingly attractive properties, with applications in diverse areas, including tribology (drills, bits, bearing surfaces, etc.), heat sinks in microelectronic and power applications, extremely hard optical coatings and free-standing windows, new semiconductor devices, and diamond-colated prosthetic materials and hiosensors.
- Rapid heat treating, particularly surface hardening, can achieve hard, wear-resistant surfaces on softer steel substrates. Solar processes can be used as less-expensive alternatives to lasers, which are now being used in the automotive industry for hardening engine and drive-train components.

- Cladding (hard coating) can produce special surface propertics on relatively inexpensive suhstrates. Solar furnace technology has successfully applied metal powders, metal oxide powders, and cermet materials to several steel substrates. One such example is shown in Figure 3. These clad materials can he used in corrosive, abrasive, high-load, or high-temperature environments in applications such as valve seats and stems, turbine blades, cutting hlades, and dies.

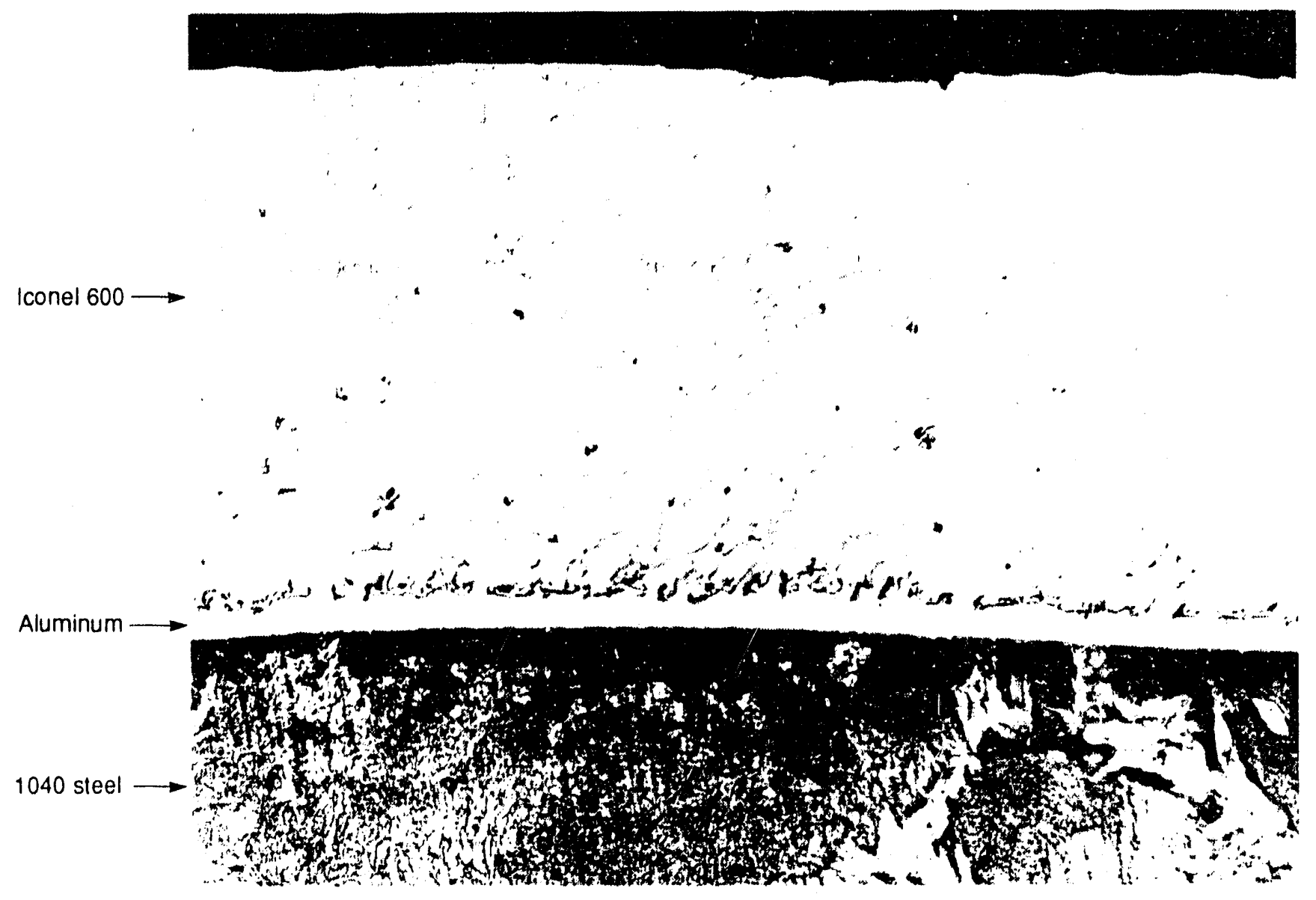

Figure 3. Photomicrograph (magnifled 200x) of a low-carbon steel clad with Inconel 600. An aluminum interlayer is used between the two layers of steel. This configuration provides superior wear and corrosion resistance characteristics. Excellent metallurgical bonds exist between the materials. 


\section{PROPOSED APPROACH}

Solar technology can help increase U.S. industry's share of the advanced materials market in the coming decades. Industry has already expressed considerable interest in the technology, and several Cooperative Research and Development Agreements (CRADAs) have been initiated with major industrial interests in metallization and joining of ceramics, and ceramic powder production.

Collectively, collaborations of this sort will serve as the foundation for this initiative. Within the initiative, a series of collaborative teams will be created consisting of the materials industry, the solar industry, universities, and NREL. Each of these teams will develop and commercialize specific materials synthesis technologies. This process will begin with research and technical feasibility, continue through process design and pilot-plant demonstration, and conclude with market development and largescale commercialization. As this serics of applications is developed, the solar industry will be positioned to commercialize the required solar technology, while the materials industry will assume the primary responsibility for commercial application of the technology.

The following specific actions are required to bring these industry collahorations to fruition:

- Identify industrial partners in specific technology areds. Through the CRADA process and other cechnology transfer mechanisms, teams will he formed to exploit substantial market opportunities.

- Develop the process through joint inclustry/ government experimentation and analysis. Process economics will he predicted and compared with conventional process alternatives, and market potential will he assessed.

- Build industry co-funded demonstrations of the technology at a pilot scale with solar industry participation.

- Involve industry in the development of commercial solar technologies. This will allow industry to lake the lead in this technology at the conclusion of the initial development phase.

\section{- ECONOMIC AND ENVIRONMENTAI. BENEFITS}

While the potential economic impact of solar synthesized materials is considerable, no long-term, detailed market analyses have been completed because of the large number of potential applications of this technology. However, even a cautious estimate, $1 \%$ of the anticipated U.S. market by the year 2000 , yields annual sales of $\$ 1.5$ hillion. Given that many current applications are energy intensive, a market of this size could displace the equivalent of 100 trillion Btus ( 0.1 quads) of energy. Using the more efficient solar processes will save energy and reduce the pollutants generated by both utility fuel combustion and conventional industrial processes. When larger U.S. and world markets are considered, the benefits associated with the solar process grow proportionally.

The case study shown in the hox on page 5 illustrates the potential benefit of solar processing in ceramic powders. However, ceramic powders represent only one small niche of the advanced materials market. Other advanced materials technolegies could reap economic and environmental henelits similar (1) those predicted for ceramic powders. Many of these technologies have already generated considerable industrial interest. For example, one U.S. eompany interested in solar-hased ceramic metallization and joining is a world leader in high-performance ceramic packages and one of the (op I0) U.S. suppliers of electronic materials. This company estimates that solar processes could save millions of dollars annually for existing products. Additionally. new products enhanced hy solar processing could yicld sales in the tens of millions of dollars.

Another potential industrial partner is seeking alternative technologies for metallization to replate existing processes that waste strategic metals and require the use of large quantities of hazardous chemicals. In this case, solar processes can minimize the waste of materials without the need for loxic chemicals. This results in a more efficient and protitahle process with minimal environmental problems.

Diamond-like coatlings are altracting considerahle attention from industry. One company is incerested in using such coatings to exiend the life of extrusion tooling. Sollar processed diamond-like 


\section{Solar Synthesis of Advanced Materials: A Case Study}

Estimates of the near-term, economic impact on specific industries show considerable promise. For example, advanced ceramic powders are used primarily for structural and electronic applications and thermal spray coatings. The estimated production in 1990 of advanced ceramic powders was 265 million pounds worth $\$ 460$ million (with prices ranging from $\$ 0.60 \mathrm{hl}$. for hard ferrite powders to $\$ 150 / \mathrm{lb}$. for various nitride powders). With an anticipated anmual growth rate of $8.5 \%$, the advanced ceramic powder market conld reach production rates of 342 million pounds worth $\$ 753$ million by the year 2000. 131

Electronic applications make up $80 \%$ of the ceramic powder market, followed by structural applications. (which have the highest growth rate, 10.5\% annually). The U.S. advanced ceramic powder business is characterized by a dozen key players, most of whom supply silicon carbide powders.

A unique, solar-based silicon carbide process, which has been demonstrated at the NREL solar furnace, has two distinct advantages over the conventional Acheson process. The first advantage is the replacement of electric energy $(9000 \mathrm{kWh} / \mathrm{ton}$ product) with solar energy. The second advantage is the production of a higher-grade powder that requires less processing for high-valned applications. Initial estimates indicate that a solar process would be economically superior to the conventional process based on the energy cost savings' alone. If the higher quality of the solar product allows significant reduction of materials processing costs, total mamufacturing costs may be cut in half.

Anmual U.S. production of silicon carbide is expected to exceed 25,000 tons/year before the end of the century, and to have annual growth over twice that of the GNP. This market would represent an anmal use of about $225 \mathrm{GWh}$ of electricity. Assuming that the energy in the conventional process is produced by coal plants, the potential total annual entissions from the production of electricity for silicon carbide manufacturing is about 23,000 tons of $\mathrm{CO}_{2}, 68$ tons of $\mathrm{NO}_{x}$ and 68 tons of $\mathrm{SO}_{x}$.

The sales prices of high-valued silicon carbide products are on the order of $\$ 12 / \mathrm{lb}$ and up. If the solar processe can cut the manufacturing costs in half, this could result in potential annual savings for the entire market on the order of tens of millions of dollars. Lower costs for silicon carbide powders may open entirely new product markets. Although the actual narket penetration of the solar processs would likely be fairly small fraction of the overall market by the end of the century, the anmual savings would still be very high relative to the $R \& D$ required to prove and commercialize the process.

coatings have attractive properties that could henefit many industries. The present world-wide market for diamond thin films, primarily for cutting tools and other hard coatings, is $\$ 2(x)$ million, with growth in the next deciade estimated to be $\$ 4$ hillion. $|4|$

These examples indicate hoth the current industrial interest in solar-hased processing technologies and the kinds of economic impacts that are anticipated. Through this initiative, these industrial applications cian he thoroughly explored to estahlish their true potential. Successful industry collahoralions developed in this initiative will pave the way for future growth and new applications that will allow for the full potential of this technology to he realized.

\section{- PROPOSED BUDGF'I}

The anticipated hudget for this initiative is intended to stimulate initial industry interest in solute synthesized advanced materials and is, therefore, relatively modest in scope. Starting in liscial yeur (FY) 1993 with funding of $\$ 1.75 \mathrm{M}$ and increasing in FY 1094 (1) $\$ 4.2 \mathrm{M}$, the 5 -year hudget (FY 1903. FY 1997) totals $\$ 2.5 \mathrm{M}$ (see Figure 4). During that 


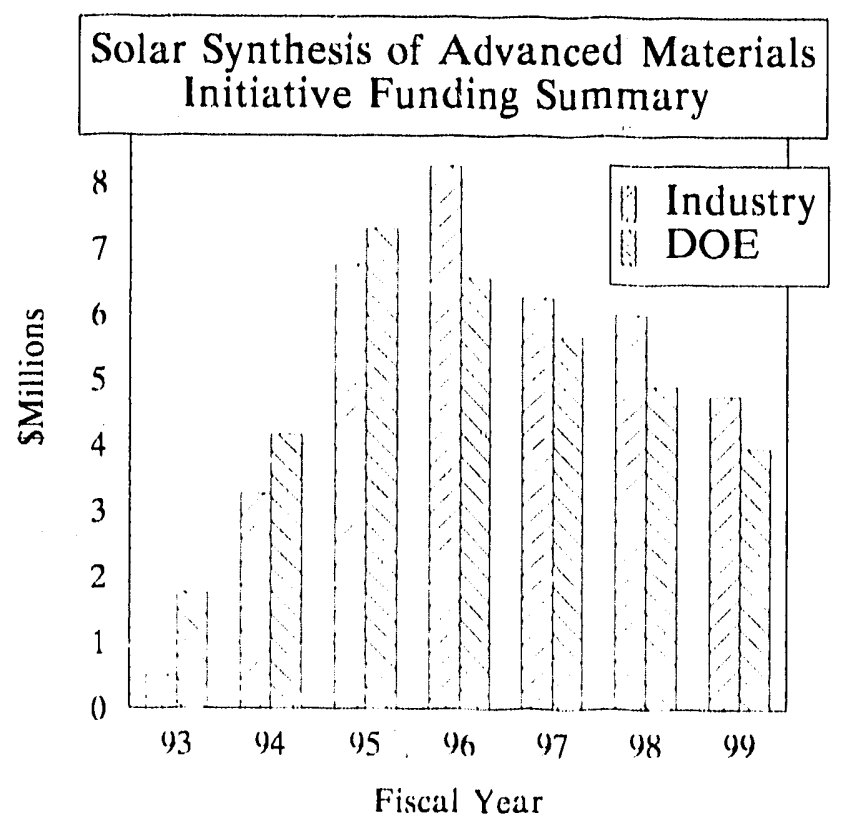

Figure 4. Proposed budget for the solar materials initiative.

5-year period, four to six industrial projects can be initiated. Industrial cost-sharing of these projects is estimated to be $60 \%$. After FY 1995 the budget decreases, as emphasis on commercialization of the technology shifts to industry (both materials and solar industries), and a mature program to identify and implement new concepts into the collaborative process is established.

\section{- REFERENCES}

1. Materials Science and Engineering for the 1990s, National Research Council, National Academy Press, 1989.

2. Emerging Technologies-A Survey of Technical and Economic Opportunities, Technology Administration, Department of Commerce, PB9()-216557, 1990.

3. Advanced Ceramic Powders for Siructural Components, Coatings, and Electronic: Applications, Business Communications $\mathrm{C}(0$. . Inc., GB-102, 1990).

4. Dicumond Thin Films-New Opportunities, International Rescarch Development, Inc., New Canaan, Connecticut, 1991. 

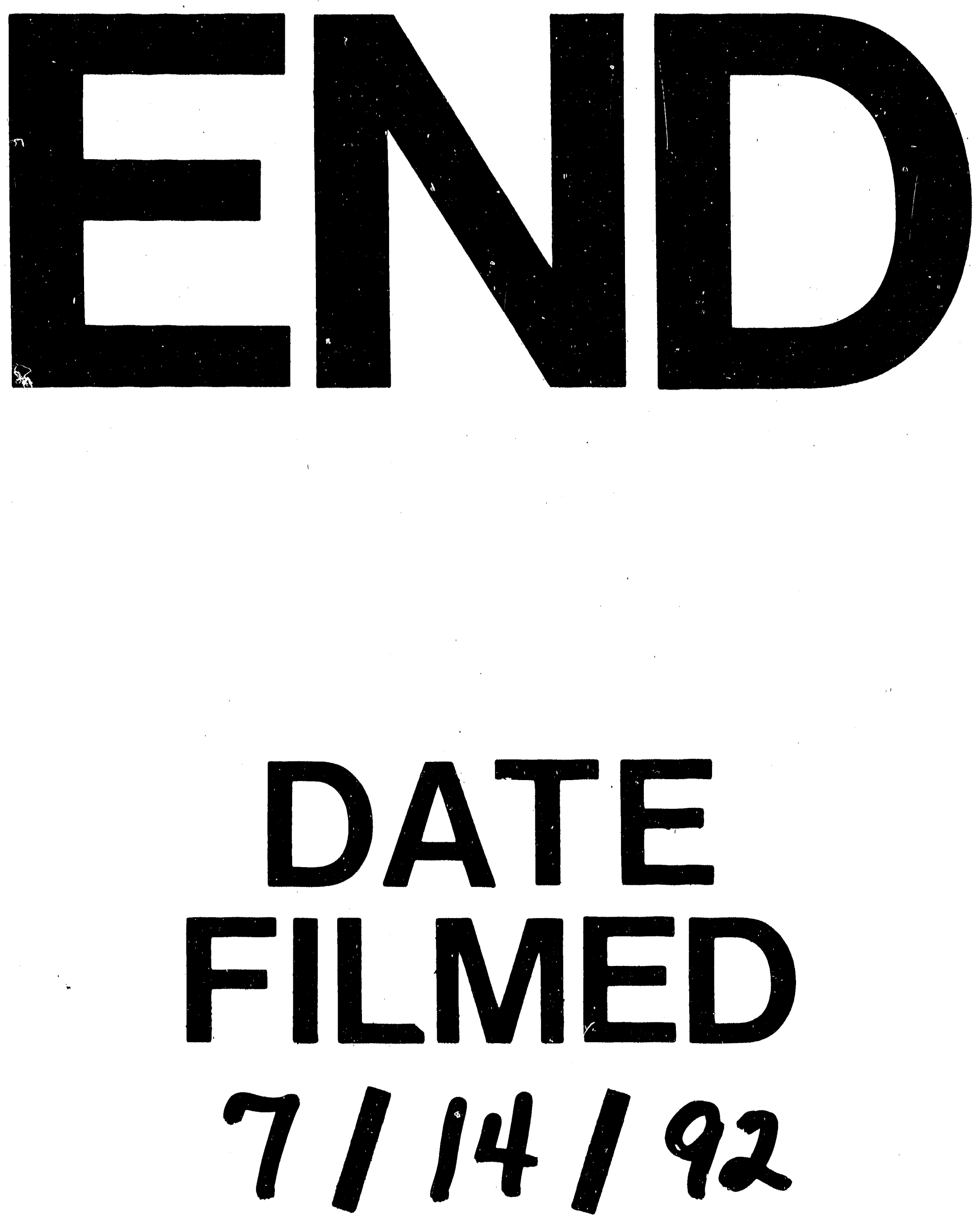

1 
